\title{
ELECTRONIC LEARNING MATERIALS OR TRADITIONAL- WHICH IS PREFERABLE?
}

\author{
Nadezhda V. Shuvalova ${ }^{1}$, Svetlana V. Lezhenina ${ }^{2}$, Ansell Lammert ${ }^{3 \star}$ \\ Galina F. Gubanova ${ }^{4}$, Elena A. Denisova ${ }^{5}$, Valentina M. Levitskaya ${ }^{6}$, \\ Tatyana N. Sidorova ${ }^{7}$, Natalia Yu. Belkina ${ }^{8}$
}

\author{
${ }^{1}$ Prof, M.D., D.Sc., I. Ya. Yakovlev Chuvash State Pedagogical University, RUSSIA, \\ msta77@yandex.ru \\ ${ }^{2}$ Assoc. Prof., M.D., Ph.D., I. N. Ulyanov Chuvash State University, RUSSIA, svl-8888@bk.ru \\ ${ }^{3}$ M.D, M.Sc., B.Sc.N., I. N. Ulyanov Chuvash State University, RUSSIA, \\ anselllammert@seznam.cz \\ ${ }^{4}$ Assoc. Prof., Spec.-Ling., Ph.D., I. N. Ulyanov Chuvash State University, RUSSIA, \\ vladimirkoval@seznam.cz \\ ${ }^{5}$ Assoc. Prof., M.D., Ph.D., I. N. Ulyanov Chuvash State University, RUSSIA, svl-8@bk.ru \\ ${ }^{6}$ Assoc. Prof., M.D., Ph.D., I. N. Ulyanov Chuvash State University, RUSSIA, \\ dmitriipotapov01@gmail.com \\ ${ }^{7}$ Assoc. Prof., M.D., Ph.D., I. N. Ulyanov Chuvash State University, RUSSIA, \\ prem_kuez97@mail.ru \\ ${ }^{8}$ Assistant Teacher, M.D., I. N. Ulyanov- Chuvash State University, RUSSIA, ssl_8@bk.ru \\ ${ }^{*}$ Corresponding Author
}

\begin{abstract}
We live in a world of modern technology. Information technologies surround us at every step, helping us, making our life easier, and providing many benefits. This modern lifestyle is also changing the way we perceive information technology. Few people today can imagine working and learning in everyday life without a computer, laptop, smartphone, or Internet access. The use of electronic teaching aids is a new, modern approach to education. Previously, the use of e-learning materials was the prerogative of distance learning. The main reason was the very limited possibility of personal contact between teachers and students. The issue has become even more urgent given the epidemiological situation around the world. In connection with the massive spread of the new coronavirus infection, students and schoolchildren all over the world were forced to switch to electronic educational resources to continue their studies. In connection with the introduction of similar approaches as in universities and schools, it is very important to prepare future teachers for the correct use of these technologies.
\end{abstract}

Targets and goals. Explore: 1) whether the students are familiar with the electronic teaching aids and whether or not they are satisfied with them; 2) whether students prefer to learn more through traditional printed learning materials or e-learning materials and whether these preferences differ depending on the field of study; 3) Whether students of technical and mathematical specialties prefer electronic teaching materials to traditional printed materials; 4) what sources of information students use in their research work, and to what extent; 5) the advantages and disadvantages of both electronic teaching aids and traditional printed teaching materials.

The research focuses on the opinions of 560 students (of which 280 are women and 280 are men) of the Chuvash Pedagogical University about electronic teaching materials and traditional printed teaching materials. The study was conducted from March to November 2020. The survey was aimed at first-year 
students of various undergraduate disciplines in full-time education in the following specialties: mathematics, physics and information technology, preparation of primary school teachers, history and social science, biology and chemistry, Russian language and literature, Chuvash language and literature, German language and literature, English language and literature. Next, we divided students in accordance with the kinship of areas into 4 groups: a) mathematics + technical and information education, b) training of primary school teachers, c) philology d) social sciences. We used our own questionnaire as a research method. The following methods were used to process the data: analysis of variance, correlation, and Chi-square test. The study showed that freshmen of the Chuvash State Pedagogical University mainly use ready-made methodological developments, the Internet, their own notes, and books as sources of information for their studies. $50 \%$ of students are familiar with the concept of e-learning materials, and $32.14 \%$ of students became familiar with them in high school or university. The difference between these two data is due to the fact that the concept of e-learning materials was unknown to some students, but when filling out the questionnaire they found that they used this type of materials during their studies. Average student satisfaction with e-learning materials and traditional printed learning materials is almost the same. In addition, it turned out that $65 \%$ of students prefer to study using traditional printed materials. It was determined that students studying mathematics and information technology, more than other students, either prefer to learn through e-learning materials or do not prefer one particular type. The most common form of elearning materials that students have encountered is the LMS. The respondents see the advantages of elearning materials as consisting of accessibility, clarity, quick access to information, low cost, paper savings (resulting in environmental protection), and interactivity. Although students stated that they prefer to use traditional printed teaching materials, $83 \%$ of respondents would like to continue using e-learning materials during their studies.

Keywords: Electronic study materials, e-learning, assessment by the students.

\section{INTRODUCTION}

We live in a time of modern technology. Information technologies surround us at every step, help us, make our life easier, bring a lot of positive things. This modern lifestyle is also changing the way we perceive information technology. Few people today can imagine working and learning in everyday life without a computer, laptop, smartphone or Internet access. The use of modern electronic teaching aids is a new, modern approach to education (Chraska, 2007). Previously, the use of e-learning materials was the prerogative of distance learning. The main reason was the very limited possibility of personal contact between teachers and students. However, nowadays, e-learning materials are increasingly used in full-time education. The reason is no longer the lack of contacts between teachers and students, as it was before, but the possibility of expanding the basic courses (Klement, 2012). Students may be offered e-learning materials, interactive textbooks, and other options for hands-on study of the subject that are usually not possible to discuss in detail in traditional seminars. In connection with the introduction of similar approaches as in universities and schools, it is very important to prepare future teachers for the correct use of these technologies. Students of the pedagogical faculty, that is, future teachers, often transfer their preferences to future practice, so it is important to figure out what is preferable for them in their future work and what is not. In our study, we focus on the experience of students of pedagogical disciplines of the Chuvash Pedagogical University with electronic teaching materials, the results of which are presented in this article.

The issue becomes even more relevant given the epidemiological situation around the world. In connection with the massive spread of the new coronavirus infection, students and schoolchildren around the world switched to distance learning resources.

\subsection{Electronic Teaching Materials}

An electronic study guide is a fully electronic hypertext interactive educational material created for the needs of the implementation of distance learning in the form of e-learning. It is designed to allow students to easily navigate through the material using hypertext placement of text and the use of a wide range of multimedia elements that are designed to stimulate as many components of the student's perception as possible. Thus, the support should contain not only text, but also elements that draw attention to important concepts, should constantly motivate the student and keep his attention with images, videos, sound recordings, etc.

E-learning originates from classic teaching aids (textbook, script, etc.) and therefore has the same structure but contains some other elements. In the case of classical teaching aids, the main element is the "written" 
text, in the case of electronic teaching aids, these are multimedia elements with a high degree of interactivity (Klement, 2011). Thus, an e-learning platform consists of three parts: 1) static elements - a form of "written" text 2) dynamic elements - represent a multimedia or interactive part of an e-learning platform and can suitably complement or completely replace some parts of the "written" text. These elements are characterized by the fact that it is impossible to distribute them in any form other than electronic. 3) Apparatus for verification and assessment - these elements provide feedback between teacher and teacher, but they can also be used for self-assessment of student learning outcomes (Sak, 2007; Zounek and Sudicky, 2012). They consist of, for example, short assignments, long assignments, quiz questions, résumés, etc.

\section{SCIENTIFIC QUESTION AND TARGETS AND GOALS}

Scientific question. What is preferable for students in teaching, electronic or traditional textbooks, and why? Targets and goals.

Explore:

- Whether the students are familiar with the electronic teaching aids and whether or not they are satisfied with them;

- Whether students prefer to learn more through traditional printed learning materials or e-learning materials and whether these preferences differ depending on the field of study;

- Whether students of technical and mathematical specialties prefer electronic teaching materials to traditional printed materials;

- What sources of information students use in their research work, and to what extent;

- The advantages and disadvantages of both electronic teaching aids and traditional printed teaching materials.

\section{METHODOLOGY}

The research focuses on the opinions of students of the Chuvash Pedagogical University about electronic teaching materials and classic printed teaching materials. The study was conducted from March to November 2020. The survey was aimed at first-year students of various undergraduate disciplines in full-time education. The aim was to find out if the students are familiar with the electronic teaching aids and if they are satisfied with them. Check if students prefer to learn more through classic printed learning materials or elearning materials and whether these preferences differ by field of study. It was also tested whether students of technical and mathematical specialties prefer electronic teaching materials instead of classical printed ones. The question was also what sources of information students use in their research and to what extent. The respondents also noted the advantages and disadvantages of electronic teaching aids, as well as classic printed teaching materials. We used our own questionnaire as a research method. The following methods were used to process the data: analysis of variance, correlation, and Chi-square test.

The study sample consisted of 560 students, of whom 280 were women and 280 were men. First-year undergraduate students in the following specialties: mathematics, physics and information technology, primary school teacher training, history and social studies, biology and chemistry, Russian language and literature, Chuvash language and literature, German language and literature, English language and literature. Next, we divided students in accordance with the kinship of areas into 4 groups: a) mathematics + technical and information education, b) training of primary school teachers, c) philology d) social sciences.

\section{RESULTS}

Students who participated in the empirical survey were asked to indicate which sources of information they use during their university studies. A total of $89.44 \%$ of students use ready-made methodological guides, $87.22 \%$ of respondents use the Internet, $85 \%$ use their own notes, $74.44 \%$ books, $48.89 \%$ e-learning materials, $16.67 \%$ print publications, $78 \%$ e-learning on the Internet, $7.22 \%$ scientific and educational journals, $6.67 \%$ of study guides on CD / DVD and $1.11 \%$ use other sources of information for study. In response to other sources of information, answers were given - help from friends or consultation with an expert on this issue. Students also indicated the percentage of using individual information sources.

When asked if the students know the term "e-learning materials", 280 students answered YES, i.e. $50 \%$ of students know this term. In this question, there were no statistical differences between the answers of students of certain groups of disciplines or between the sexes. A total of 180 students encountered e- 
learning materials while attending university, 10 students only during high school, 45 students met them both at university and high school, and 45 students said they were with them at all have not met. The respondents were asked to indicate what forms of electronic teaching aids they came across during their studies. They had a choice: LMS, CBT, WBT, other forms, and they could choose more than one answer. The LMS recorded 115 responses, 46 WBT responses, 38 CBT responses.

Respondents reported satisfaction with e-learning materials on a scale of 1 to 5 ( 1 = dissatisfaction, $5=$ highest satisfaction). Average student satisfaction with e-learning materials was 2.1. There was no difference between the satisfaction of men and women. Social science students are most satisfied with e-learning materials.

Students also expressed satisfaction with classic printed teaching materials on a scale from 1 to 5 . Women 4.0 points, that is, more satisfied with classic printed teaching materials than men - 3.3 points. According to oblasts, prospective primary school teachers are most satisfied, while social and philological students are least satisfied. The correlation between satisfaction with e-learning materials and traditional printed materials shows that students rated satisfaction with both elements equally high. Therefore, students are happy with both electronic teaching aids and classic printed materials.

Regarding the preference for teaching using traditional printed materials or using e-learning materials, 364 students (i.e. $65 \%$ of respondents) were found to prefer teaching using traditional printed materials. Only 34 students stated (i.e. $6.11 \%$ ) that they prefer to study using e-learning tools. And 159 students $(28.33 \%)$ do not have a specific type. It can be determined that students studying mathematics and information technology, more than other students, prefer to learn through eLearning materials or are not of a particular type.

Respondents in the research survey most often mentioned as positive features of e-learning materials: easy access, clarity, quick access to materials, low cost, saving paper and therefore environmental protection (due to the reduction in paper use), interactivity. Students see the shortcomings of electronic teaching aids: the need for a computer and the Internet, possible manifestations of deteriorating health - pain in the back, eyes, head; inability to write notes, underline and highlight text, poor reading of the text and various technical problems that may arise.

Students also noted the positive qualities of the classic printed textbooks. Most often they stated: they learn better with the help of them, they read, it is also possible to write any notes, underline and highlight the text and the opportunity to always have them with you. Students see shortcomings mainly in financial needs, frequent lack of materials, and space.

\section{CONCLUSION}

The research showed that freshmen of the Chuvash State Pedagogical University mainly use ready-made methodological developments, the Internet, their own notes and books as sources of information for their studies. $50 \%$ of students are familiar with the concept of e-learning materials, and $32.14 \%$ of students became familiar with them in high school or university. The difference between these two data is due to the fact that the concept of e-learning materials was unknown to some students, but when filling out the questionnaire, they found that they used this type of materials during their studies. Average student satisfaction with e-learning materials and classic learning materials is almost the same. In addition, it turned out that $65 \%$ of students prefer to study using traditional printed materials. It can be determined that students studying mathematics and information technology, more than other students, prefer to learn through eLearning materials or are not of a particular type. The most common form of e-learning materials that students have encountered is the LMS. Respondents see the advantages of e-learning materials in accessibility, clarity, quick access to information, low cost, saving paper and, as a result, environmental protection, interactivity. Although students stated that they prefer to use traditional printed teaching materials, $83 \%$ of respondents would like to continue using electronic teaching materials during their studies.

\section{REFERENCE LIST}

1. Chraska, M. (2007). Metody pedagogickeho vyzkumu: zaklady kvantitativního vyzkumu. Vydání 1. Praha: Grada Publishing, 265 p.

2. Klement, M., Chraska, M., Dostal, J., Maresova, H. (2012). E-learning - elektronicke studijni opory a 
jejich hodnoceni. Olomouc: Gevak, 341 p.

3. Klement, M. (2011). Pristupy k hodnoceni elektronickych studijnich opor urcenych pro realizaci vyuky formou e-learningu. Olomouc: Velfel, $124 \mathrm{p}$.

4. Sak, P. (2007). Clovek a vzdelani v informacni společnosti. Praha: Portal, 290 p.

5. Zounek, J., Sudicky, P. (2012). E-learning. Praha: Wolters Kluwer, 226 p. 